\title{
Myogenic and morphogenetic defects in the heart tubes of murine embryos lacking the homeo box gene $N k x 2-5$
}

\author{
Ian Lyons, ${ }^{1,3}$ Linda M. Parsons, ${ }^{3}$ Lynne Hartley, Ruili Li, Jane E. Andrews, ${ }^{2}$ Lorraine Robb, \\ and Richard P. Harvey ${ }^{4}$ \\ The Walter and Eliza Hall Institute of Medical Research, Post Office, Royal Melbourne Hospital, Parkville 3050, Australia
}

The murine homeo box gene $N k \times 2-5$ is expressed in precardiac mesoderm and in the myocardium of embryonic and fetal hearts. Targeted interruption of $N k \times 2-5$ resulted in abnormal heart morphogenesis, growth retardation and embryonic lethality at $\sim 9-10$ days postcoitum (p.c.). Heart tube formation occurred normally in mutant embryos, but looping morphogenesis, a critical determinant of heart form, was not initiated at the linear heart tube stage (8.25-8.5 days p.c.). Commitment to the cardiac muscle lineage, expression of most myofilament genes and myofibrillogenesis were not compromised. However, the myosin light-chain $2 V$ gene ( $M L C 2 V$ ) was not expressed in mutant hearts nor in mutant ES cell-derived cardiocytes. $M L C 2 V$ expression normally occurs only in ventricular cells and is the earliest known molecular marker of ventricular differentiation. The regional expression in mutant hearts of two other ventricular markers, myosin heavy-chain $\beta$ and cyclin D2, indicated that not all ventricle-specific gene expression is dependent on Nkx2-5. The data demonstrate that $N k \times 2-5$ is essential for normal heart morphogenesis, myogenesis, and function. Furthermore, this gene is a component of a genetic pathway required for myogenic specialization of the ventricles.

[Key Words: Nkx2-5; tinman; homeo box gene; heart; cardiac; gene targeting]

Received April 19, 1995; revised version accepted May 24, 1995.

The myogenic lineage of the vertebrate heart is specified during or soon after gastrulation in response to the events of mesoderm induction (Sater and Jacobson 1990b; Logan and Mohun 1993; Montgomery et al. 1994). Little is known about the molecular signals that guide this process. A paradigm for myogenic lineage commitment is provided by the action of the myogenic regulatory factors (MRFs) in skeletal muscle development. Here, four transcription factors (myod, myogenin, myf5, and MRF4) of the basic helix-loop-helix (bHLH) superfamily, activate the myogenic program by binding to "E-box" sequence motifs present in the promoters and enhancers of muscle-specific genes (Weintraub et al. 1991; Buckingham 1994; Lassar and Munsterberg 1994; Olson and Klein 1994). When expressed in embryonic tissues or in a variety of nonmuscle cell lines, individual MRFs can initiate myogenesis (Weintraub et al. 1989; Rupp et al. 1994) and have therefore been referred to as "master regulatory factors" (Weintraub et al. 1991). Sup-

Present addresses: 'Bresatec Ltd., 39 Winwood Street, Thebarton 5031 Australia; ' Department of Paediatrics, University of Melbourne, Royal Children's Hospital, Parkville 3052 Australia.

${ }^{3}$ These authors contributed equally to this work.

${ }^{4}$ Corresponding author. porting the in vitro findings, mice that carry null mutations in myod and myf5 lack myoblasts and muscle (Rudnicki et al. 1993). MRF activity is modulated by association with other factors, including E2 bHLH proteins, c-jun, retinoblastoma protein, pl07, and MEF2A (Murre et al. 1989; Bengal et al. 1992; Gu et al. 1993; Kaushal et al. 1994; Schneider et al. 1994).

Mammalian cardiac and skeletal muscles express several myofilament proteins in common. However, cardiac muscle does not express the known MRFs (Olson 1993) and mice lacking MRF function do not have heart defects (Rudnicki et al. 1993). Furthermore, transcription of several heart muscle genes is independent of E-box-mediated regulation (Mar et al. 1988; Navankasattusas et al. 1992; Parmacek et al. 1992; Amacher et al. 1993; Christensen et al. 1993; Vincent et al. 1993; Grepin et al. 1994). bHLH factors may modulate expression of some myofilament genes in the heart (Sartorelli et al. 1992; Litvin et al. 1993; Molkentin et al. 1993; Burgess et al. 1994; Navankasattusas et al. 1994), but because cardiac myogenesis is subverted in cardiocyte-fibroblast heterokaryons (Evans et al. 1994), they probably do not act as dominant master regulators.

These findings leave open the question of how the cardiac myogenic lineage is established and regulated during development. Several transcription factors, including 
GATA4, MEF2, Hf-1b, SRF, Egr-1, MCBF/TEF-1, and USF, have been shown to participate in myogenic gene regulation in cultured cardiocytes (Miwa and Kedes 1987; Gupta et al. 1991; Farrance et al. 1992; Zhu et al. 1993; Edmondson et al. 1994; Navankasattusas et al. 1994). However, a developmental hierarchy for these genes has not been established.

Recent studies in invertebrates suggest that members of the NK class of homeo domain proteins (Kim and Nirenberg 1989) play an essential role in establishment of myogenic lineages during development. The Drosophila gene tinman is expressed in primitive mesoderm and later in the heart and gut muscle lineages (Bodmer et al. 1990). Embryos that lack tinman function do not develop heart or gut muscle progenitor cells nor a subset of body wall muscles (Azpiazu and Frasch 1993; Bodmer 1993). Drosophila bagpipe is also required for visceral muscle differentiation (Azpiazu and Frasch 1993), and in bagpipe mutants, some visceral muscle cells change their fate to body wall muscles or gonadal mesoderm (Azpiazu and Frasch 1993). An NK class homeo box gene from Caenorhabditis elegans, ceh-22, may have a role in pharyngeal myogenesis (Okkema and Fire 1994).

Homeo box genes of the NK class may also function in early heart development in vertebrates (Komuro and Izumo 1993; Lints et al. 1993; Tonissen et al. 1994). A murine NK gene, Nkx2-5, is expressed in early cardiac progenitor cells prior to activation of the myogenic program (Lints et al. 1993). Nkx2-5 is then expressed across the myocardial layer of embryonic and fetal hearts, and transcripts can be detected in the adult heart (Komuro and Izumo 1993; Lints et al. 1993). Expression also occurs in developing tongue and stomach muscles as well as in the spleen and pharyngeal floor (Lints et al. 1993).

The Nkx2-5 gene has been cloned from Xenopus laevis (Tonissen et al. 1994) and is highly related in sequence and expression pattern to the mouse gene. Transcripts accumulate during gastrulation in an area that may correspond to the heart morphogenetic field (Sater and Jacobson $1990 a_{\text {; }}$ Tonissen et al. 1994), a progenitor pool from which the heart is derived by both positive and negative inductive influences (Jacobson and Sater 1988).

The homology between Nkx2-5, XNkx2-5, and Drosophila tinman and the similarities in their expression patterns suggest an early and conserved role for $N k \times 2-5$ in heart muscle development (Lints et al. 1993; Bodmer 1995). To further assess the function of $N k \times 2-5$, we have used gene targeting in ES cells to interrupt the gene within the homeo box. Embryos homozygous for the interrupted allele displayed heart morphogenetic defects at embryonic day 8.5 . A beating linear heart tube developed, but looping morphogenesis, a critical determinant of heart form, was not initiated. Although most myofilament genes appeared to be expressed normally in mutant hearts, expression of the myosin light-chain $2 \mathrm{~V}$ $(M L C 2 V)$ gene was not activated. This molecular phenotype demonstrates that $N k \times 2-5$ is a positive regulator of at least one component pathway of the cardiac myogenic program. $M L C 2 V$ expression is normally restricted to the ventricular chambers and their progenitors $\left(\mathrm{O}^{\prime} \mathrm{Brien}\right.$ et al. 1993). $N k x 2-5$ expression is therefore essential for specialized ventricular myogenesis.

\section{Results \\ Targeted interruption of the Nkx2-5 gene}

We have shown previously that $N k x 2-5$ lies within the $t$-complex on mouse chromosome 17 and is missing in a deletion variant, $t^{h 20}$, of the $t$-haplotype, $t^{6}$ (Himmelbauer et al. 1995). However, $t^{\text {h2O }}$ embryos die as homozygotes before $N k \times 2-5$ is normally expressed and are therefore uninformative with respect to $N k \times 2.5$ function.

To generate a loss-of-function $N k \times 2-5$ mutation, gene targeting in ES cells was undertaken. A replacementtype targeting vector (Thomas and Capecchi 1986) was constructed in which sequences coding for helix 3 of the homeo domain were interrupted by insertion of a $n e o^{R}$ gene cassette (pgkNEO; Fig. 1A). Helix 3 is virtually invariant among homeo domain proteins and is responsible for high-affinity, sequence-specific DNA binding (Gehring et al. 1994).

DNA isolated from electroporated and selected E14 ES cell clones (see Materials and methods) was screened by Southern blotting for EcoRI fragments characteristic of the targeted allele (see Fig. 1A). Four clones (1 in 125) displayed the expected $5.3-\mathrm{kb}$ mutant fragment. More extensive Southern analysis confirmed that one $\mathrm{Nkx2-5}$ allele had been correctly targeted in all lines and that random integration of the targeting vector had not occurred (data not shown). Three of the four targeted clones transmitted the mutant allele through the germ line, and the mouse strains produced from these clones showed the same heart phenotype (discussed below).

\section{The Nkx2-5 ${ }^{-1-}$ mutation is embryonic lethal}

We anticipated that embryos lacking the $\mathrm{Nkx2}-5$ protein would die from heart defects during early fetal development. Litters from heterozygous crosses were therefore examined $\sim 10.5$ days postcoitum (p.c.), and several embryos were observed to be severely growth retarded when compared with littermates (Fig. 2A). DNA was prepared from embryos and analyzed by Southern blotting (Fig. 1B). Only the 5.3-kb fragment was detected in growthretarded embryos, indicating that these were homozygous for the targeted allele.

A PCR assay performed on conceptus-derived DNA extracted from the yolk sac and amniotic membranes was used to genotype $>1200$ 8.5- to 10-day p.c. embryos produced from heterozygous crosses. Because no embryos of normal appearance and growth scored as homozygotes in this assay, the observed growth retardation phenotype is fully penetrant.

Figure $1 \mathrm{C}$ depicts the somite number /a measure of developmental stage) of individual homozygous mutants plotted against the average somite number in normal embryos from the same litter. Mutant embryos began to deviate from normal developmental rate at the 15 - to 


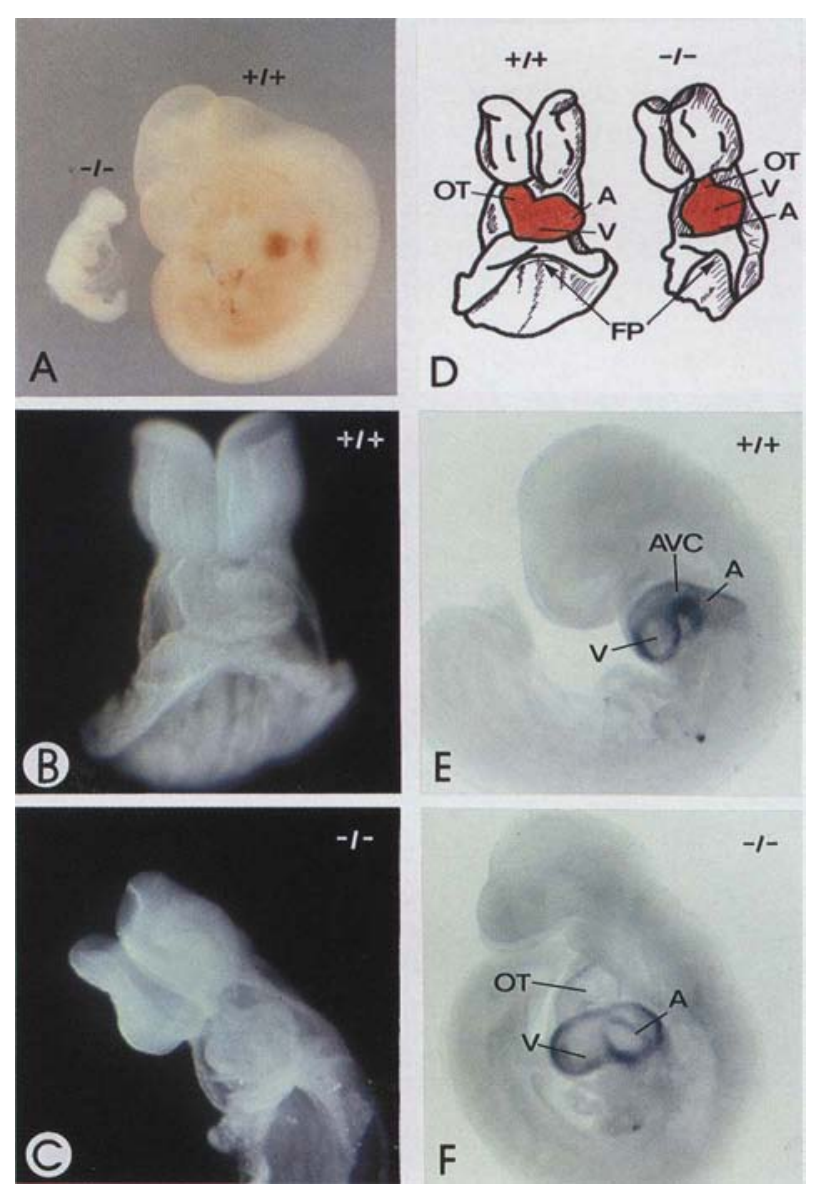

Figure 1. (A) Structure of the $N k \times 2-5$ loci and gene targeting vectors. The two targeting vectors differed only in the selection cassette (pgkNEO or pgkHYGROpA) inserted into the unique BglII site ( $\mathrm{Bg})$ within the homeo domain, as shown above and below the line. Probe 1 indicates the fragment used for screening and genotyping. (B) BamHI; (E) EcoRI; (H) HindIII. (B) Southern genotype analysis of individual embryos harvested at 10.5 days p.c. from an $N k \times 2-5^{+1-} \times N k \times 2-5^{+1-}$ mating. The Southern blot, carrying embryo DNA digested with EcoRI, was hybridized with probe 1 (see Fig. 1A) that discriminates between the targeted and wild-type $N k \times 2-5$ alleles. Embryos labeled MUTANT were growth retarded. The remaining embryos (NORMAL) showed normal growth and structure. All growthretarded embryos were homozygous for the targeted $N k \times 2-5$ allele (see text). (C) Developmental status of $N k \times 2 \cdot 5^{-1}$ embryos. The figure shows the somite number of individual $N k \times 2-5^{-1-}$ embryos at the time of sacrifice, plotted against the average somite number in normal $1+1+;+1-1$ embryos from the same litter. $N k \times 2-5^{-1-}$ embryos deviated from normal development (broken line) around the 15- to 20 -somite stage. No mutant embryos were observed with $>24$ somites.

20-somite stage ( 9 days p.c.) but never achieved a somite number $>24$.

\section{A cardiac defect in $\mathrm{Nkx} 2-5^{-1-}$ embryos}

Macroscopically and histologically, $N k \times 2-5^{-1}$ embryos were indistinguishable from normal littermates at the linear heart tube stage (8-8.25 days p.c.). At 8.5 days of development, however, mutants displayed an obvious cardiac defect (Fig. 2B-D), whereas all other structures appeared normal. Wild-type sibling embryos of the same age had begun looping morphogenesis-a pronounced rightward looping of the heart tube that marks the beginning of chamber formation and results in a clear phys-

A

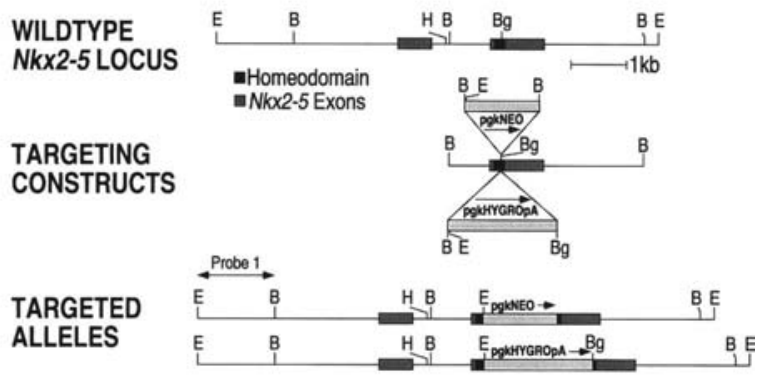

B

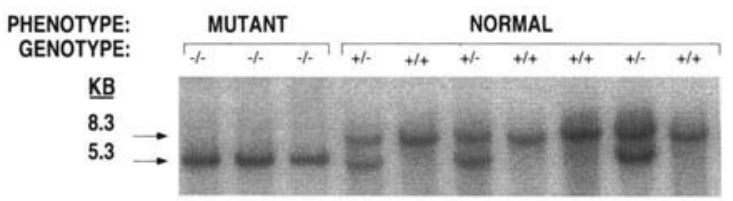

C

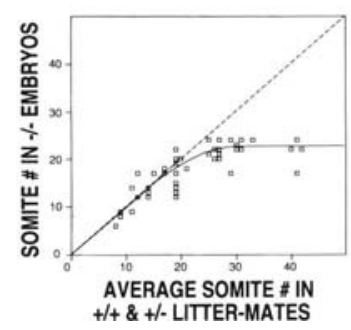

Figure 2. Physical appearance of $N k \times 2-5^{-1-}$ embryos. $(A)$ Homozygous mutant $(-1-1$ and wild-type sibling $(+1+)$ at 11 days p.c. The mutant embryo corresponded in size to normal embryos of $8.5-9$ days p.c. (B) Wild-type $(+/+1$ embryo at 8.5 days p.c., showing the beginning of looping morphogenesis in the heart. $(C) N k \times 2-5^{-1-}$ embryo at 8.5 days p.c., from the same litter as the embryo in $B$. (D) Schematic representation of the embryos depicted in $B$ and $C$. The hearts are colored red. (OT) Outflow tract; (A) atrium; (V) ventricle; (FP) foregut pocket. Mutant embryos had an abnormal linear heart tube with a bulbous ventricular chamber and stepped ventricular-outflow tract junction. $(E, F)$ Wild-type $(+1+)$ and mutant $(-1-)$ embryos, respectively, at $9-9.5$ days p.c. The hearts were highlighted by whole-mount in situ hybridization with a digoxygenin-labeled $\alpha$-cardiac actin probe. In the mutant, forward growth of the ventricle occurred in the absence of looping morphogenesis. Note the open atrioventricular chamber, lack of an atrioventricular canal and stepped ventricular-outflow tract junction. $\langle\mathrm{A}\rangle$ Atrium; (AVC) atrioventricular canal; (OT) outflow tract; (V) ventricle. 
ical separation between the primitive atrial and ventricular regions (Fig. 2D). Mutant embryos were not able to initiate this process. Their hearts remained in a linear conformation and developed a bulbous character with a somewhat narrow outflow tract and no demarcation between atrial and ventricular chambers.

At 9-9.5 days p.c., homozygous mutant hearts were still essentially linear (Fig. 2E,F), although the atrial region was displaced to the left, as in normal embryos. Some atrioventricular (AV) demarcation became apparent (see Fig. 2F and below), but the AV canal did not elongate. The junction between the ventricular region and the outflow tract was noticeably stepped (Fig. $2 \mathrm{C}, \mathrm{D}, \mathrm{F})$. Around 9 days p.c., homozygous embryos developed pericardial edema, also seen in embryos that die from cardiac defects as a result of other mutations (Chen et al. 1994; Jacks et al. 1994). Although mutant hearts beat and erythrocytes could be seen in heart chambers, blood circulation appeared poor. Mutant embryos at 9 days p.c. also began to show growth and developmental retardation and onset of generalized edema. Later changes included distension of the AV chamber and sinus venosa. The mutant hearts adopted a variably irregular shape that was often biased toward the left and clearly devoid of the dextroloop.

The morphogenetic defects, retardation of growth and development, onset of edema, and distension of major veins suggest the cause of death in Nkx2-5 mutants to be early hemodynamic insufficiency.

\section{Histological analysis of $\mathrm{Nkx2-5^{-1- }}$ hearts}

Figure 3 shows representative sections through the hearts of a normal embryo that contained 22 somites and a homozygous mutant sibling embryo with 20 somites. The normal heart is highly looped at this stage, and its wall is trilaminar in structure, consisting of myocardial and endocardial layers (Fig. 3A) separated by cardiac jelly (Viragh and Challice 1977). In homozygous mutant embryos, the structure and cellular integrity of the heart wall appeared normal (Fig. 3C). The presence of cardiac jelly was demonstrated by alcian blue staining for hyaluronic acid (data not shown). Consistent with macroscopic assessment, mutant hearts were largely linear in form with an open AV chamber and no evidence of looping morphogenesis. A cleft was evident between the apparent primitive atrial and ventricular chambers (large arrowed in Fig. $3 \mathrm{Cl}$, but the AV canal did not narrow or elongate and endocardial cushions did not form.

In the ventricular region, differentiation of the inner mural layer of the myocardium into trabeculae carneae occurred poorly, if at all (Fig. 3B,D). The development of trabeculae establishes a spongiform network of myocytes that is infiltrated by the endocardium to form intertrabecular sinusoids. In mutants, no interaction between the endocardium and the myocardial wall was evident. A higher power view of the ventricular myocardium (Fig. 3D) showed a stage of development similar to the normal pretrabecular ventricle, characterized by a

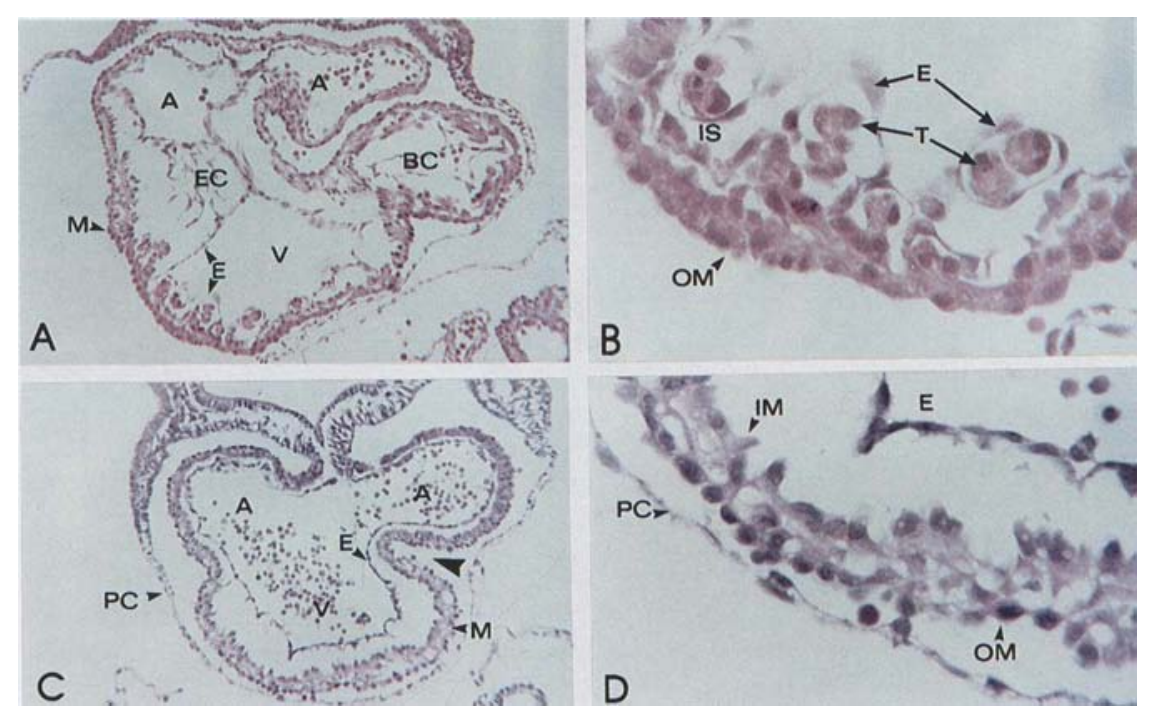

Figure 3. Histological analysis of wildtype and sibling mutant hearts at 9-9.5 days p.c. The mutant embryo shown was chosen because it had reached a stage of development (20 somites) relatively close to that of its siblings /average somite number $=22$ ). The mutant embryo nevertheless showed some growth retardation. Sparse cellular density in the head and trunk region and minor evidence of necrosis were found by histological analysis. $|A|$ Section through the heart of a wild-type embryo of 22 somites. The section reveals the contours of the highly looped heart. Endocardial cushion formation and trabeculation of the ventricle are evident. $(B)$ High-power view of the ventricular region of the section shown in $A$. The endocardium has extensively penetrated the trabecular myocardium to form the intertrabecular sinusoids. $(C)$ Section through the presumptive atrial and ventricular heart chambers of an $N k \times 2-5^{-1-}$ mutant embryo of 20 somites. The large arrowhead indicates the cleft between the presumptive atrial and ventricular chambers. This can be seen macroscopically in Fig. 2F. Note the lack of endocardial cushion formation, trabeculae, and association between the endocardium and myocardium. $(D)$ High-power view of the presumptive trabecular region of the section shown in $C$. Note the decreased adhesion between myocytes of the inner mural layer of the myocardium. (A) Atrium; (BC) bulbus cordis; (E) endocardium; (EC) endocardial cushion; (IM) inner mural layer of the myocardium; (IS) intertrabecular sinusoid; (M) myocardium; $(\mathrm{OM})$ outer mural layer of the myocardium; $(\mathrm{PC})$ pericardium; $(\mathrm{T})$ trabeculae; $(\mathrm{V})$ ventricle. 
Figure 4. Myogenesis in mutant hearts and embryoid bodies. (A) Semiquantitative/comparative RT-PCR analysis of gene expression in dissected normal $|+|+;+1-\mid$ and mutant $\mid-1-1$ hearts at 9 days p.c. (Lanes 1-4) The progressive fivefold serial dilutions of RT cDNA that were the templates for PCR amplification using gene-specific primers (see Materials and methods). The wedges indicate the direction of increasing dilution. After electrophoresis on agarose gels, PCR products were analyzed by Southern blotting with radiolabeled gene-specific probes and autoradiography. Primers specific for the $\alpha$-cardiac actin $(\alpha \mathrm{CA})$, myosin heavy-chains $\alpha$ and $\beta(\mathrm{MHC} \alpha, \mathrm{MHC} \beta)$, myosin light-chains $1 \mathrm{~A}, 1 \mathrm{~V}, 2 \mathrm{~A}$, and $2 \mathrm{~V}$ (MLClA, MLClV, MLC2A, MLC2V), and $\beta$-cytoskeletal actin ( $\beta$-ACTIN) were used. $C 1$ and $C 2$ are control lanes where RNA and reverse transcriptase were omitted from the RT-PCR reactions, respectively. $(B)$ Kinetics of appearance of beating cardiogenic foci in wild-type $(+/+;)$ and mutant $(-1-; \square)$ embryoid bodies. $(C)$ RNase protection analysis of myofilament gene expression in homozygous and heterozygous mutant and wild-type embryoid bodies after 13 days in culture. RNA isolated from embryoid bodies of the three genotypes was compared to a variable quantity of wild-type adult heart RNA. Yeast tRNA was used as a specificity control. Myofilament probe abbreviations are as in A. A glyceraldehyde-phosphate dehydrogenase (GAPDH) probe was used to control for mRNA levels. $M H C \alpha / \beta$ is a rat crossspecies probe that detects both $M H C \alpha$ and $M H C \beta$ mRNAs as a complex of four bands. The upper two bands detected correspond to $M H C \beta$, because they are not detected in adult heart RNA in which $M H C \alpha$ is the predominant isoform.

decrease in adhesion between cardiocytes of the inner mural layer (Viragh and Challice 1977).

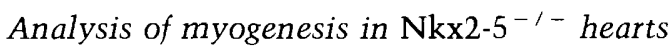

The histological characteristics of mutant hearts and their ability to beat suggests that the myogenic program is established normally. To analyze myogenesis further, myofilament gene expression was examined using a semiquantitative, reverse transcription-polymerase chain reaction (RT-PCR) assay, performed on RNA samples extracted from day-9 mutant and stage-matched normal sibling hearts using primers specific for muscle actin and myosin isoform genes (Fig. 4A). Cytoskeletal $\beta$-actin primers were used to normalize the amount of input cDNA.

Primers specific for $\alpha$-cardiac actin $(\alpha C A)$, myosin light-chain $1 A(M L C 1 A)$, myosin light-chain $1 V(M L C 1 V)$, myosin light-chain $2 A(M L C 2 A)$, myosin heavy-chain $\alpha$ $(M H C \alpha)$, and myosin heavy-chain $\beta(M H C \beta)$ revealed comparable levels of cognate mRNAs in normal and mu-
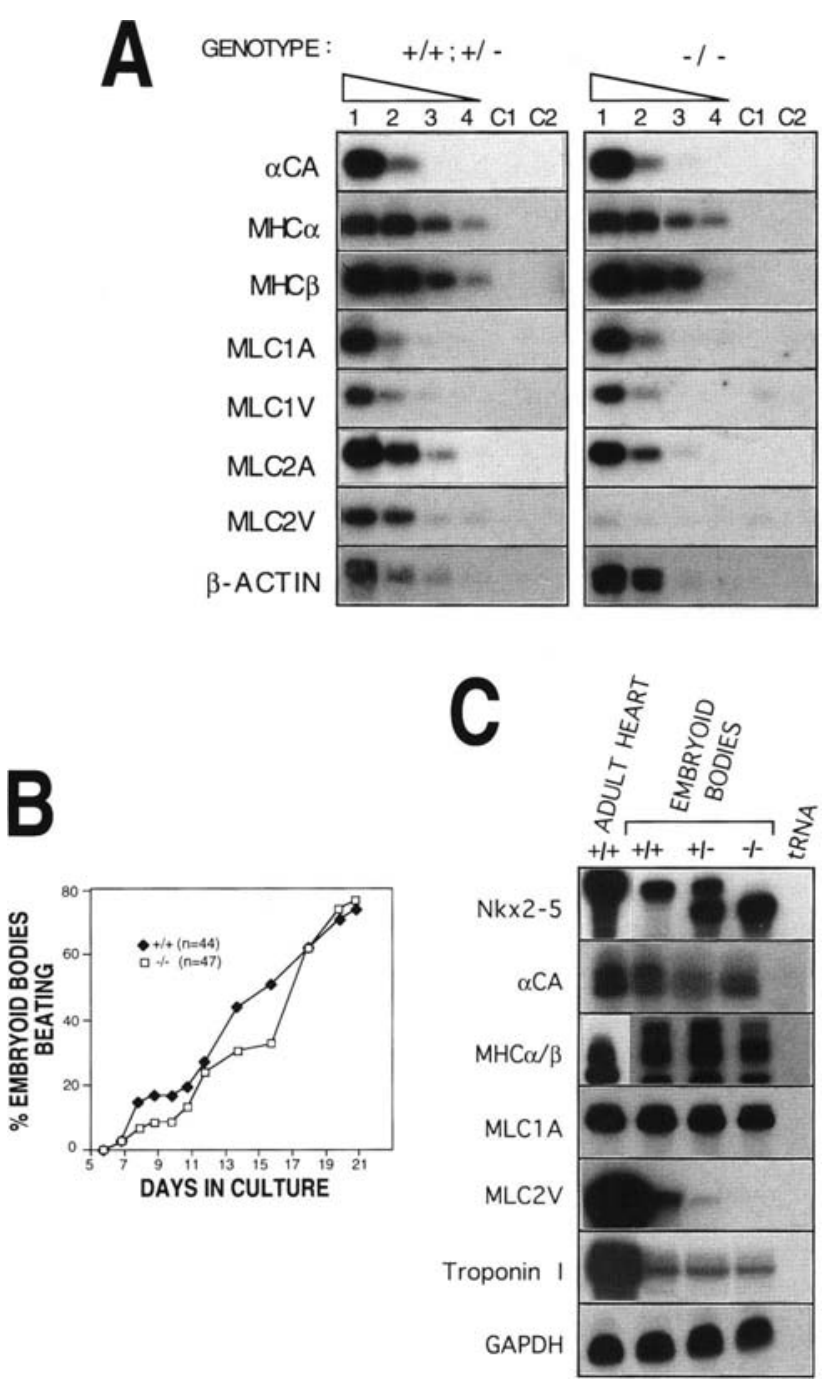

tant hearts. However, transcripts from the myosin lightchain $2 \mathrm{~V}(M L C 2 V)$ gene were markedly reduced in homozygous mutants. By comparing the wild-type and mutant data, we estimate that the abundance of $M L C 2 \mathrm{~V}$ transcripts is reduced by one to two orders of magnitude in mutants.

\section{Analysis of myogenesis in $\mathrm{Nkx} 2-5^{-1-}$ embryoid bodies}

The developing vertebrate heart is able to compensate for substantial loss of progenitor cells, a concept referred to as "regulation" (Jacobson and Sater 1988). It is possible that in mutant embryos the capacity of mesodermal cells to enter the cardiac lineage is reduced, despite the fact that a beating heart tube forms. We have exploited the ES cell system to examine this issue. ES cells, when allowed to differentiate in vitro, form complex embryoid bodies consisting of many tissue types, including single or multiple foci of rhythmically beating cardiac muscle cells (Wobus et al. 1991). In this system, cardiomyogen- 
esis is uncoupled from heart organogenesis and may not be subject to regulation.

A second round of gene targeting was performed on one targeted ES cell clone using a vector containing a hygro $^{R}$ cassette (Fig. 1A). One line that carried a targeted interruption in both $N k \times 2-5$ alleles was obtained from 500 screened. When differentiated in vitro, cardiogenic foci appeared at the same time and accumulated at the same rate and to the same final frequency as in wild-type lines (Fig. 4B). Therefore, loss of the Nkx2-5 gene does not appear to affect the propensity of mesodermal cells to produce cardiomyocytes.

We have analyzed myofilament gene expression in wild-type and mutant embryoid bodies (Fig. 4C). Total RNA was extracted from wild-type, heterozygous, and homozygous embryoid bodies after 13 days of differentiation and analyzed using an RNase protection assay. Specific probes for $N k \times 2-5, \alpha-C A, M H C \alpha / \beta, M L C 1 A$, $M L C 2 V$, troponin $I$, and GAPDH (as a control) were used. All myofilament probes, except that for $M L C 2 V$, showed similar levels of cognate transcripts in wild-type, heterozygous and homozygous mutant embryoid bodies. $M L C 2 V$ mRNA levels were dramatically reduced in homozygous mutant cultures, and intermediate levels were observed in the heterozygous mutant line. Thus, in the absence of $N k \times 2-5$ function, the $M L C 2 V$ gene was not activated, whether in the context of heart development in vivo or in an in vitro system where cardiomyogenesis is uncoupled from organogenesis.

The Nkx2-5 probe used in this analysis spans the homeo domain. Because the targeted allele has an interruption within sequences coding for the homeo domain, the size of the RNA fragment protected in the mutant lines was altered. The analysis demonstrates that the lines examined have the expected targeted genotype and normal or slightly elevated levels of expression from the mutant alleles (see Discussion).

\section{Ultrastructural analysis of $\mathrm{Nkx2-5^{-1- }}$ cardiocytes}

Thin sections of normal and $N k \times 2-5^{-1-}$ mutant hearts have been examined using transmission electron microscopy (Fig. 5). Mutant and normal cardiocytes were indistinguishable. Ultrastructural features included an abundance of mitochondria, extensive deposition of short subsarcomeric myofilament arrays generally organized around single Z-lines, and the development of electrondense, specialized intercellular junctions (desmosomes and facia adherens) (Goncharova et al. 1992). These findings support the gene expression studies and further suggest that cardiomyogenic commitment and myofibrillogenesis are not inhibited in the absence of the $N k \times 2-5$ gene.

In situ analysis of gene expression in $\mathrm{Nkx} 2-5^{-1-}$ embryos

Whole-mount in situ hybridization has been used to confirm the expression data generated by RT-PCR (Fig. 6). Using an $M L C 2 A$ probe, a comparable level of expression
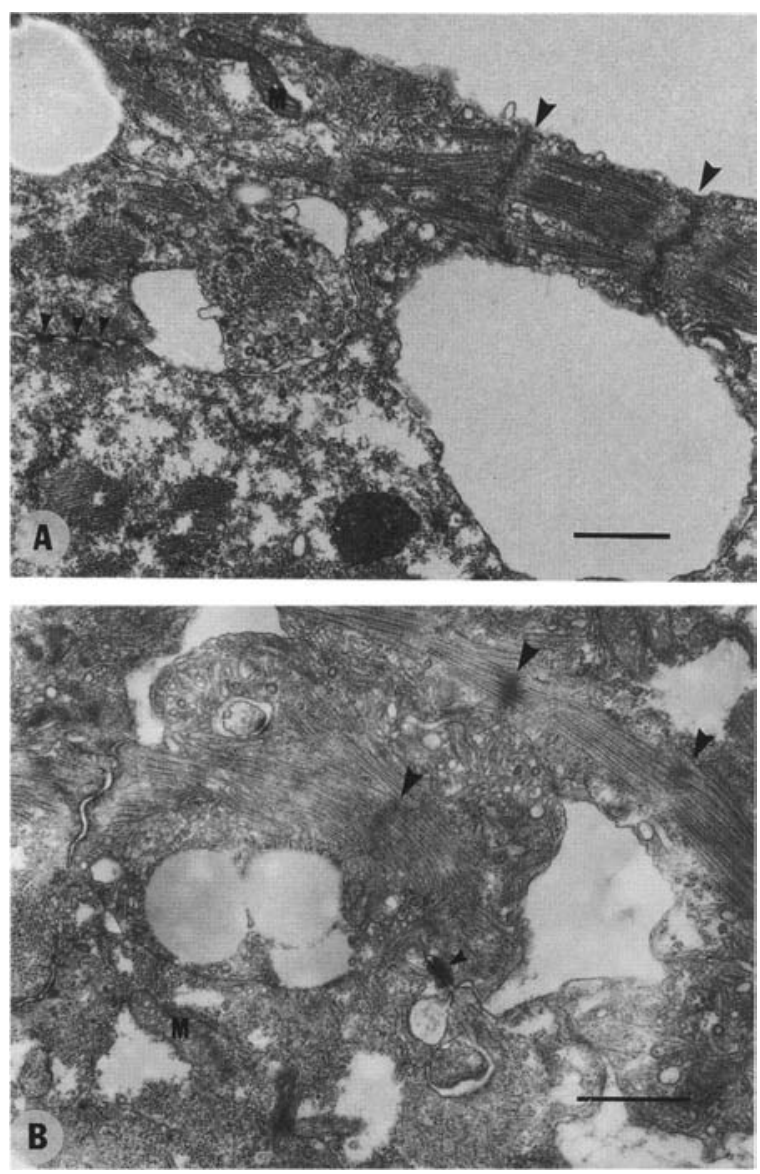

Figure 5. Ultrastructural analysis of ventricular myocytes of wild-type $(A)$ and $N k \times 2-5^{-1-}$ mutant $(B)$ hearts. Note myofilament deposition surrounding forming Z-lines (large arrowheads) and facia adherens/desmosome cellular junctions (small arrowheads). (M) Mitochondria. Bar, $1 \mu \mathrm{m}$.

was found across the myocardium in both mutant and normal sibling embryos when analyzed at 9 days p.c. (Fig. 6A). Similar results were obtained for $\alpha C A$ (see Fig. $2 \mathrm{E}, \mathrm{F}$ ) and $M L C 1 A$ (data not shown).

A high level of $M L C 2 V$ expression was found in normal embryos (Fig. 6C,D). As reported previously, expression is restricted to the primitive left ventricle and the bulbocordal region from which the right ventricle develops (O'Brien et al. 1993). In whole-mount preparations, expression was first visible around 8.0 days p.c. in paired lateral regions and in one or more "threads" of cells across the axis (Fig. 6B). Although the origins and movement of chamber primordia have not been examined in detail in the mouse, we assume that these cells represent ventricular progenitors because $M L C 2 V$ expression was clearly ventricle-specific a short time later at the linear heart tube stage (Fig. 6B). A comparison of $M L C 2 V$ and $N k \times 2-5$ expression highlighted the restricted nature of $M L C 2 V$ expression within the heart primordia (Fig. 6B). These data demonstrate that positional information has 
Figure 6. Whole-mount in situ hybridization analysis of gene expression in normal $1+1+;+1$ $-)$ and mutant $(-/-)$ embryos. (A) Expression of $M L C 2 A$ in several normal and mutant embryos ranging from 8.5-9.5 days p.c. Comparable levels of expression are seen. $(B)$ Examination of the onset of $M L C 2 V$ expression during heart tube formation. Expression of $M L C 2 \mathrm{~V}$ was compared with that of $N k \times 2.5$ at $\sim 8$ days p.c. $M L C 2 V$ expression was seen in paired cardioblasts pools (arrowhead), as well as in one or more threads of cells joining these pools. Nkx2-5 is expressed throughout the myocardial progenitors (Lints et al. 1993). The embryo probed with $N k x 2-5$ was slightly younger than the comparable $M L C 2 V$ embryos, as judged by extent of headfold formation. Expression of $M L C 2 V$ at the linear heart tube stage at $\sim 8.25$ days p.c. was restricted to the ventricle. $(C, D)$ Comparison of $M L C 2 V$ expression in wild-type and mutant embryos at 8.5 and 9 days p.c., respectively. $M L C 2 \mathrm{~V}$ expression was absent in most cells of the mutant myocardium. $(E)$ Left sided view of a 8.5- to 9-day mutant embryo showing $M L C 2 V$ expression in a small patch of cells (arrowhead) at the dorsal side of the abrupt ventricular-outflow tract junction. $(F \mid M E F 2 C$ expression in wild-type and mutant embryos at 8.5-9 days p.c. A similar pattern was observed in both wildtype and mutant hearts. (V) Ventricle.
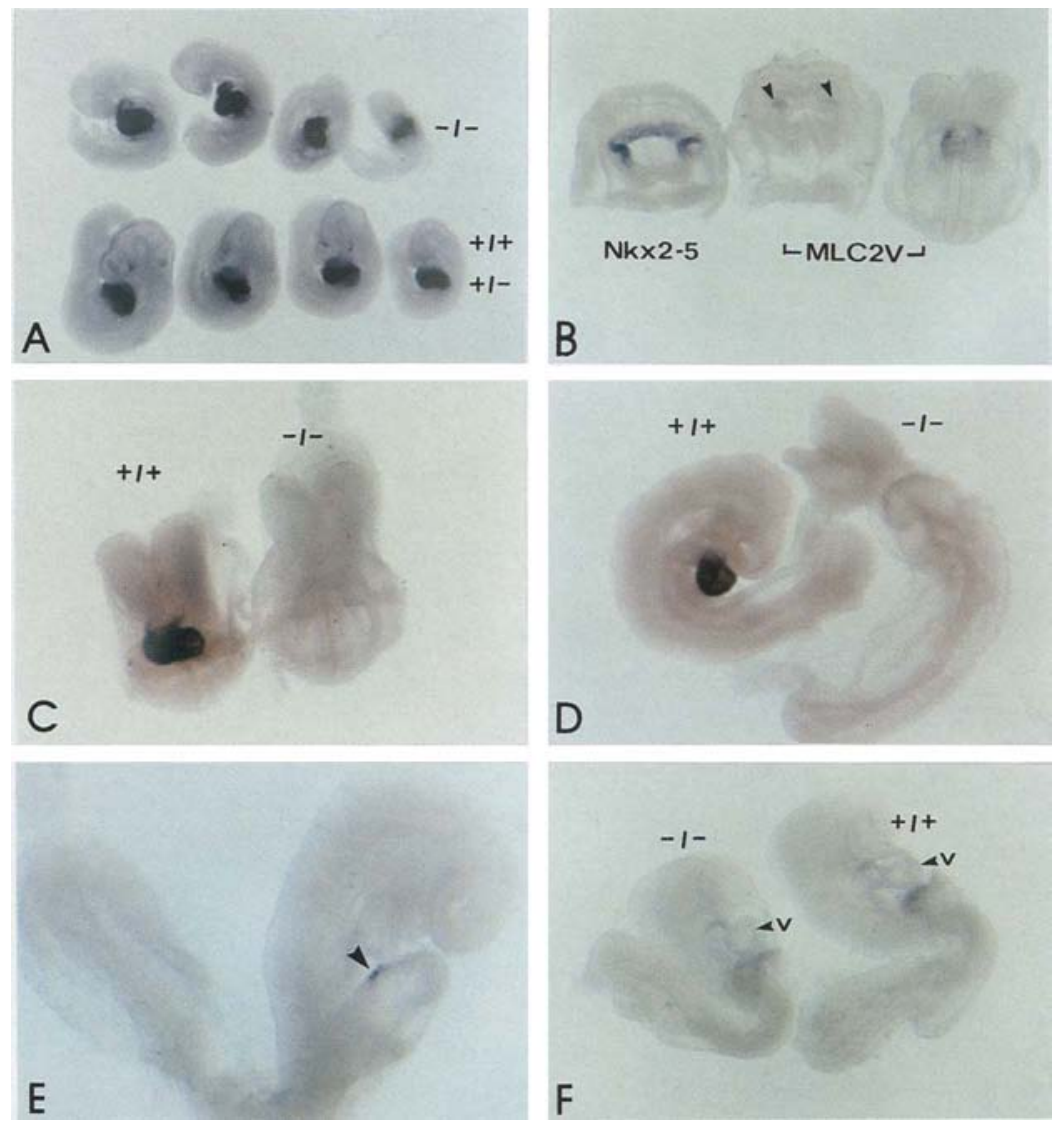

been established in the myocardium before or during heart tube formation.

In $N k \times 2-5^{-1-}$ mutant embryos, the $M L C 2 V$ gene was not expressed in the majority of cells of the ventricular myocardium (Fig. 6C,D). Analysis of a range of stages between 7.75 and 9.5 days p.c. (Fig. 6C,D; data not shown/ precluded the possibility of an initial activation phase that could not be maintained. However, we observed a small population of cells that expressed a low level of $M L C 2 V$ on the dorsal side of mutant hearts, at the abrupt junction between the primitive ventricular region and its outflow tract (Fig. 6E). Thus, a limited number of cells showed $N k x 2-5$-independent $M L C 2 V$ expression (see Discussion).

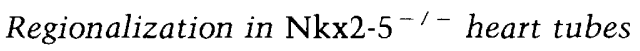

In the mouse, ventricle-specific expression of the $M L C 2 V$ gene at 8 days p.c. is the first indication that regionally restricted programs of gene expression have been activated in the myocardium (see Fig. 6B; O'Brien et al. 1993). As shown above, $M L C 2 V$ expression was drastically reduced in $N k \times 2-5^{-1}$ mutant hearts, raising the possibility that $N k \times 2-5$ plays a regulatory role in heart regionalization or chamber specification.

There are few molecular markers of regional specification within the early heart tube with which to investigate this issue. Most myofilament isoform genes are initially expressed throughout the entire myocardium and do not become restricted to different chambers until heart tube morphogenesis is well under way (Lyons et al. 1990; Lyons 1994). However, $M H C \beta$ expression becomes restricted to the ventricular region around 9-10 days p.c (Lyons et al. 1990) and can be used in mutant embryos as a ventricle-enriched marker. In separate studies (L. Hartley and R.P. Harvey, unpubl.) we have found that expression of the cyclin D2 gene is specific to the ventricular region from as early as 8.5 days p.c. Figure 7 shows the results of in situ hybridization experiments to sections of normal and mutant embryos at 9 days p.c. Hybridization to normal embryos with an $M L C 1 A$ probe highlighted both the atrial and ventricular chambers of the developing myocardium (Fig. 7B). In contrast, the cyclin $D 2$ and $M H C \beta$ probes hybridized only to the ventricular chamber (Fig. $7 \mathrm{C}, \mathrm{D}$ ). The cyclin $\mathrm{D} 2$ gene was expressed in other regions of the embryo at this time.

In Nkx2-5 $5^{-1-}$ mutant embryos, the MLC1A probe hybridized to the whole myocardium (Fig. 7F). However, $M H C \beta$ transcripts were enriched in the apparent ventricular region (see histology above) with relatively sharp AV boundaries (Fig. 7G). A low level of $M H C \beta$ hybridization was also seen in the atrial region, as expected in developmentally retarded mutants (see Fig. 1C); full restriction of $M H C \beta$ expression to the ventricle is not complete until 9-10 days p.c. (Lyons et al. 1990). cyclin D2 transcripts were also enriched in the apparent ventricular 

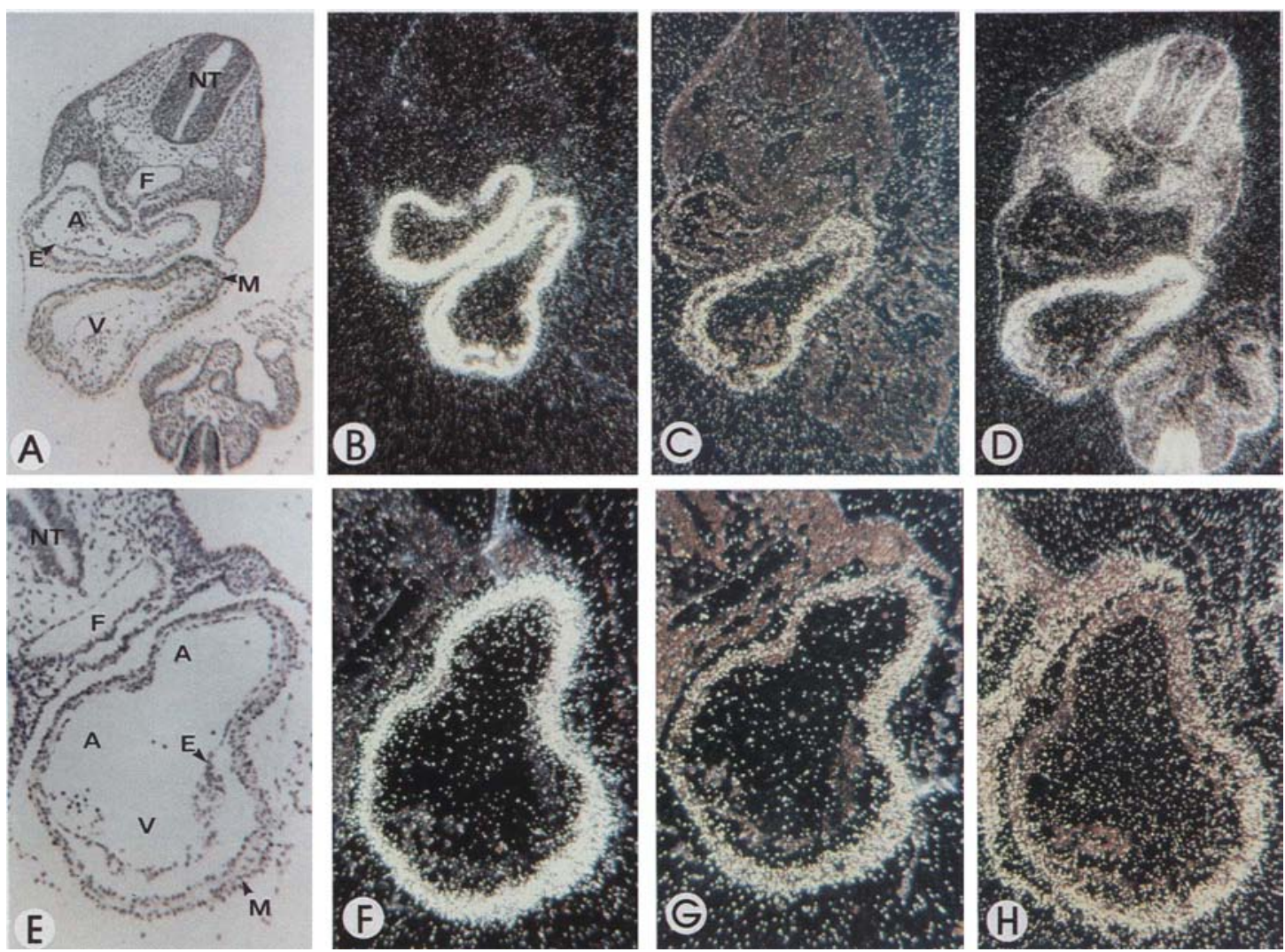

Figure 7. In situ hybridization analysis of regionally expressed markers in wild-type and mutant hearts at 9 days p.c. $|A, D|$ Wild-type embryo. $(E-H)$ Mutant embryo. $(A, E)$ Histology sections stained with hematoxylin and eosin. $(B, F)$ Sections hybridized to a $M L C 1 A$ probe, revealing both atrial and ventricular chambers of the heart. $(C, G)$ Sections hybridized with a $M H C \beta$ probe, showing ventricle specificity in the wild-type embryo and ventricular enrichment in the mutant. $(D, H)$ Sections hybridized with a cyclin $D 2$ probe, showing broad expression throughout the embryo but ventricle specificity in wild-type and mutant hearts. (A) Atrium; $(E)$ endocar$\operatorname{dium}_{\text {; }}(\mathrm{F})$ foregut; $(\mathrm{M})$ myocardium; (NT) neural tube; (V) ventricle.

region, in a pattern similar to that of $M H C \beta$, but with less distinct boundaries (Fig. $7 \mathrm{H}$ ).

Other experiments also suggested that regionalization in mutant hearts had occurred normally. The MEF2C gene is expressed in cardiogenic progenitor cells and across the early heart tube (Edmondson et al. 1994). In our whole-mount experiments, we observed a decrease in expression within the ventricle around 9 days p.c., whereas expression was retained at a low level in the truncus arteriosis and sinus venosa (Fig. 6 F). In a similar fashion, expression of the $M L C 2 A$ gene initially occurs across the myocardium but then diminishes in the sinus venosa and truncus arteriosis as a prelude to becoming fully restricted to the atria (Kubalak et al. 1994). $N k x 2$ $5^{-1-}$ hearts also showed these modulations in MLC2A and MEF2C expression (Fig. 6A,F; data not shown).

\section{Discussion}

Studies on the MRF and MEF2 transcription factors have established a paradigm for lineage commitment and differentiation during skeletal myogenesis (Olson and Klein 1994). However, MRFs are not expressed in the heart and the regulatory networks that control cardiac myogenesis remain to be determined. Evidence suggests that mammalian skeletal muscle development may be a poor model for cardiac myogenesis (see introductory section).

The homeo box gene $N k \times 2-5$ is one of three transcription factor genes ( $N k \times 2-5$, GATA4, MEF2C) expressed in murine cardiogenic mesoderm and that encode candidate regulators of cardiac myogenesis (Lints et al. 1993; Edmondson et al. 1994; Heikinheimo et al. 1994). In this paper we address the function of Nkx2-5 in heart development using a gene targeting strategy. The engineered mutation reported here disrupts a critical region of the homeo domain, that responsible for sequence-specific DNA binding. Stable transcripts are produced from the mutant allele, at least in embryoid bodies, so it is therefore possible that a truncated protein is expressed. Although it is unlikely that such a protein would have normal function, we cannot say for certain that the mutation represents a null allele. Similarly, a dominantnegative action for the protein cannot be ruled out, although this also seems unlikely because heterozygous animals, which would express the protein, appeared normal with no indication of cardiac dysfunction. 
Embryos homozygous for the mutant $N k x 2-5$ allele displayed abnormal hearts at 8.5 days p.c. and died over the next 2 days, apparently from hemodynamic insufficiency. A normal beating linear heart tube formed, but the process of looping morphogenesis was not initiated. Looping is a critical determinant of heart form and the beginning of a series of complex morphogenetic events leading to chamber and valve formation. Defects in looping, as highlighted in the iv/iv mouse (Layton et al. 1980 ), lead to severe and multiple malformations of the heart and in humans may be the antecedent of a range of congenital heart conditions.

Other morphogenetic processes, notably trabeculation and endocardial cushion formation, were also blocked in $N k \times 2-5^{-1-}$ hearts. Although a role for $N k \times 2-5$ in these processes is implied, it is possible that the defects are secondary to arrest of looping and poor hemodynamic performance. Morphogenetic changes during heart development must be compatible with, and may depend upon, normal heart function.

In addition to the morphogenetic defects, we have identified a myogenic defect in $N k \times 2-5^{-1-}$ hearts. Whereas several myofilament genes were expressed at normal levels, the $M L C 2 V$ gene was expressed in only a few cells of the mutant myocardium (see below) and at only very low levels in mutant embryoid bodies. $M L C 2 \mathrm{~V}$ expression is normally ventricle-specific. Loss of the MLC2V protein from the differentiating ventricular chamber would result in a regulatory light-chain composition equivalent to that of the atrium, where MLC2A is the predominant isoform. Because different myosin isoforms confer different physiological properties on muscle cells (Malhotra et al. 1979), this isoform transition may have exacerbated the poor hemodynamic performance of mutant hearts, thus contributing to the demise and death of homozygotes.

An intriguing observation was that a small cluster of cells on the dorsal side of mutant hearts was able to express the $M L C 2 V$ gene. Three hypotheses could account for the observation. First, $N k \times 2-5$ may be essential for the survival or proliferation of ventricular precursor cells that would normally be programmed to express $M L C 2 V$. In this case, the rare $M L C 2 V$-positive cells would represent those that survive death or an unamplified founder pool. In a more extreme case, $N k \times 2-5$ may be essential for activation of the whole ventricular myogenic pathway, in which case ventricular cells would not be specified at all in mutant hearts, except for a few by an unknown mechanism. Finally, $N k x 2-5$ could be essential for expression of $M L C 2 V$ but not necessary for expression of other ventricle-specific genes. In the rare dorsal subset of cells, this dependence could be alleviated, perhaps by expression in these cells of other homeo domain proteins.

To help distinguish between these possibilities, we have asked whether other markers of ventricular cardiocytes are present in the expected position in mutant hearts. The histological characteristics of the myocardial wall in mutant embryos suggested that a primitive ventricle had been formed, although later events in ventric- ular development, such as trabeculation, were blocked. We did not detect histological signs of cell death in early mutant hearts, suggesting that ventricular cells were not deleted through apoptosis. Using in situ hybridization, we have demonstrated that the ventricle-specific markers $M H C \beta$ and cyclin $D 2$ are only expressed in the indicated ventricular region. These findings, supported by normal modulations in expression of $M E F 2 C$ and $M L C 2 A$ across the heart tube, suggest that heart regionalization has not been blocked and that the ventricular chamber has indeed been specified. Therefore, the simplest model to account for our findings is that $N k \times 2-5$ and $M L C 2 V$ lie in a common genetic pathway. $\mathrm{Nkx} 2-5$ protein may activate the $M L C 2 V$ promoter directly, or indirectly via regulation of other transcription factors. We cannot fully exclude the possibility that deletion of a cardiocyte population in mutant hearts contributes to the morphogenetic defects. Regional gene expression may, in part, be informed by signals extrinsic to the heart, in which case boundaries could be reestablished in the mutant heart after loss of a founder-cell population. In the light of the complete absence of heart and gut muscle progenitors in Drosophila tinman mutants, this possibility must be considered in future analysis of the phenotype.

The coincident appearance of morphogenetic and myogenic defects in $N k \times 2-5^{-1-}$ hearts suggests that the processes could be linked. Previous studies show that inhibition of the myogenic program with BUdR or of myofibrillogenesis with cytochalasin-B disrupts heart looping (Manasek 1976). Furthermore, local application of cytochalasin-B to the linear heart tube can invert the direction of looping (situs invertus) (Itasaki et al. 1991). Models suggest that the orientation of cardiac myofibres in the developing heart tube direct, or limit, its morphogenetic options (Manasek et al. 1978; Itasaki et al. 1991). Our studies raise the intriguing possibility that heart looping is dependent on the initiation of a specialized ventricular myogenic program and that the morphogenetic defects in $N k \times 2-5^{-1-}$ hearts are a direct consequence of lack of $M L C 2 \mathrm{~V}$ expression. However, heart looping occurs in conjunction with, and may also depend upon, differential ventricular cell growth and local changes in cardiocyte shape and adhesion (Manasek et al. 1972; Rumyantsev 1977; Viragh and Challice 1977). In addition to $M L C 2 V, N k x 2-5$ may control genes required for these processes.

$N k \times 2-5$ is a close relative of Drosophila tinman, which is essential for formation of heart and gut muscle progenitor cells (Azpiazu and Frasch 1993; Bodmer 1993). Although the precise function of tinman is not known, it has been proposed that it provides early mesoderm with the competence to respond to downstream regulators of muscle development (Azpiazu and Frasch 1993). Of relevance to the broader perspective of cardiac development is whether $N k \times 2-5$ has a role in the mouse analogous to tinman in flies (Bodmer 1995). If the $N k x 2-5^{-1-}$ phenotype is considered in isolation, it is clear that $N k \times 2-5$ is not essential for mesodermal cells to enter the cardiac muscle lineage, a conclusion strongly supported by his- 
tological, ultrastructural, and gene expression studies, as well as the normal appearance of cardiomyocytes in mutant embryoid bodies. However, during the evolution of vertebrates, there appears to have been an increase in the number of NK genes in the genome. Five murine genes highly related to $N k \times 2-5$ have been described to date /see Lints et al. 1993|, and some of these are expressed in the heart. By RT-PCR, we have detected expression of $N k \times 2-2$ and $N k \times 2-6$ in embryonic hearts at 9 days p.c. (data not shown). In Xenopus laevis, Nkx2-3 has an embryonic expression pattern almost identical to that of XNkx2-5 (S. Evans, pers. comm.; Tonissen et al. 1994). As observed in other gene families, there may be partial functional redundancy between individual $N k x 2$ family members. Thus, an essential tinman-like function for $N k \times 2-5$ in cardiac muscle commitment may be masked by expression of other $N k x 2$ genes in the heart.

As Azpiazu and Frasch (1993) predict, tinman probably controls downstream regulators of cardiac development. The myogenic defect observed in Nkx2-5 ${ }^{-1-}$ hearts may reflect a subset of a tinman-like function in developing cardiocytes. The lack of $M L C 2 V$ expression in Nkx2$5^{-1-}$ hearts implies a defect in one branch of the regulatory hierarchy that orchestrates the murine myogenic program. The findings are still compatible with $N k \times 2-5$ and tinman having a related function and for the existence of an ancient regulatory pathway at the core of cardiac myogenesis (Bodmer 1995). As noted above, mammalian skeletal myogenesis may be a poor model for heart muscle development. A more useful model may be the myogenic lineages of invertebrates in which NK genes, such as tinman, function.

The knockout studies presented here demonstrate an essential role for the $N k \times 2-5$ gene in heart myogenesis and morphogenesis. They extend the work on Drosophila tinman and bagpipe to show that NK homeo box genes play key regulatory roles in vertebrate as well as invertebrate muscles and provide clues to the evolution and development of the mammalian heart (Scott 1994; Bodmer 1995). Parallel genetic and molecular studies in mice and flies should facilitate dissection of mammalian heart development.

\section{Materials and methods}

\section{ES cells and embryoid bodies}

E14 ES cells from the 129/Ola strain (Hooper et al. 1987) were cultured using standard protocols (Wurst and Joyner 1993) on $\gamma$-irradiated STO fibroblasts in high glucose Dulbecco's modified Eagle medium (DMEM) containing $15 \%$ fetal calf serum and $10^{3} \mathrm{U} / \mathrm{ml}$ of leukemia inhibitory factor (LIF). Embryoid bodies were produced for analysis of beating cardiogenic foci by the hanging drop method (Wobus et al. 1991). ES cells were harvested in differentiation medium (DMEM, 15\% fetal calf serum) and transferred to uncoated tissue culture dishes for $1 \mathrm{hr}$ to allow fibroblasts to adhere. After recovery of nonadherent cells, grids of $50-\mu$ l drops containing $\sim 800$ cells were set up on the lids of tissue culture dishes (Costar), then inverted over phosphate-buffered saline (PBS) to reduce desiccation. After 2 days, individual aggregates were transferred to single wells of 24-well culture dishes (Costar) coated with $0.5 \%$ agarose in DMEM.
After 4 days on agarose and two media changes, aggregates were transferred to individual wells coated in gelatin and allowed to differentiate. Adherent colonies were scored daily for beating foci.

Bulk embryoid body cultures for analysis of myofilament gene expression were prepared by seeding a suspension of $10^{6} \mathrm{ES}$ cells in $50 \mathrm{ml}$ of differentiation medium into nonadherent bacterial dishes (Greiner). After 6 days in culture, aggregates were transferred in bulk to gelatin-coated tissue culture plates (Falcon) and allowed to adhere and differentiate for a further 7 days. At this time, $\sim 50 \%$ of colonies showed beating foci. RNA was isolated from cultures for RNase protection analysis using the guanidinium thiocyanate-phenol method (Chomzynski and Saachi 1987).

\section{Gene targeting}

E14 ES cells $\left(2 \times 10^{7}\right)$ were electroporated with targeting vector (500 $\mu \mathrm{F}, 200 \mathrm{~V}$; Bio-Rad Gene Pulser fitted with capacitance extender) and selected in culture media containing as appropriate, G418 $(250 \mu \mathrm{g} / \mathrm{ml})$ for 8 days or hygromycin $(175 \mu \mathrm{g} / \mathrm{ml})$ for 5 days (Wurst and Joyner 1993). Cells were cultured on neomycin-resistant or hygromycin-resistant STO fibroblasts in the presence of LIF. Resistant colonies were split into two, one portion for freezing (Wurst and Joyner 1993) and the other for expansion and DNA extraction (Laird et al. 1991). DNA was screened for targeting events by Southern analysis (see text and Fig. 1A). After thawing, targeted ES cells were injected into (C57Bl/6) $\times \mathrm{C} 57 \mathrm{Bl} / 10 \mathrm{~J}$ )F2 blastocysts that were then transferred to pseudopregnant $(\mathrm{C} 57 \mathrm{Bl} / 6 \mathrm{~J} \times \mathrm{CBA}) \mathrm{F} 1$ female recipients (Bradley 1987). Chimeras were identified by coat color and mated to $[\mathrm{C} 57 \mathrm{Bl} / 6] \times \mathrm{C} 57 \mathrm{Bl} / 10 \mathrm{~J} / \mathrm{F} 1$ mice to establish the knockout line. Offspring carrying the disrupted $N k \times 2-5$ allele were identified using a PCR assay (see below) on tail biopsy DNA (Laird et al. 1991).

\section{Genotyping of embryos and mice}

The yolk sacs and amnion of embryos were dissected free of maternal tissue and washed twice in MT-PBS. DNA was extracted as described (Moens et al. 1993). DNA was isolated from tail biopsies of weaned mice as described (Laird et al. 1991). A two-reaction PCR assay was used to genotype embryos and mice. PCR cycle conditions were as follow: $95^{\circ} \mathrm{C}$ for $30 \mathrm{sec}_{\text {; }}$ $60^{\circ} \mathrm{C}$ for $30 \mathrm{sec}_{;} 72^{\circ} \mathrm{C}$ for $30 \mathrm{sec}$ for 30 cycles. The primers used for detection of the wild-type allele were 5 '-cagtggagctggacaaagcc-3' (sense Nkx2-5) and 5'-tagcgacggttctggaacca-3' lantisense $N k \times 2-5)$. Primers for detection of the mutant allele were 5'-cggaagccacgcgtgctctt-3' (sense $N k \times 2-5$ ) and 5'-gctccagactgccttgggaaa- $3^{\prime}$ (antisense pgk promoter).

\section{Reverse transcriptase-PCR assay}

Total RNA was prepared (Chomzynski and Saachi 1987) from 3 to 5 hearts dissected from normal $(+1+;+1-1$ or mutant $1-1$ - ) embryos at 9 days p.c., treated with RNase-free DNase I (Boehringer Mannheim) and resuspended in $20 \mu \mathrm{l}$ of water. Firststrand cDNA synthesis was performed using $2 \mu$ l of heart RNA preparation with AMV reverse transcriptase (Promega) and oligold $\left.\mathrm{T}_{15}\right)$ primer, as per manufacturer's instructions. Up to five cDNA reactions were pooled, and fivefold serial dilutions were used in subsequent PCR reactions. PCR amplification was performed using oligonucleotide primers specific for $M H C \alpha$, $M H C \beta$, and $M L C 2 A$, as described previously (Robbins et al. 1990; Kubalak et al. 1994), and for other myofilament genes as follows (sense and antisense, respectively): $\beta$-actin, $5^{\prime}$-gtgggccg- 
ctctaggcaccaa-3', 5'-ctctttgatgtcacgcacgatttc-3'; $\alpha$-CA, 5' -agagtatgatgaggcaggcc-3', 5'-atgactgatgagagatgggg-3'; $M L C 1 A, 5^{\prime}$-acacactctcttcacctggc- $3^{\prime}, 5^{\prime}$-atgaaactccaagctggggc- ${ }^{\prime} ; M L C 1 V, 5^{\prime}-$ at atcatggcgagctgagcc- $3^{\prime}, 5^{\prime}$-agagtgactgcaggagtccg-3'; and $M L C 2 V$, $5^{\prime}$-tgttcctcacgatgtttggg-3', 5'-ctcagtccttctcttctccg3-'. PCR reactions were performed on a Bresatec PTC- 100 thermal controller using $4 \mu \mathrm{l}$ of heart cDNA preparation, $1 \mu \mathrm{M}$ of each oligonucleotide primer, and 1 unit of Taq polymerase (Cetus) in $30 \mu \mathrm{l}$ of buffer $\left(50 \mathrm{~mm} \mathrm{KCl}, 10 \mathrm{mM}\right.$ Tris- $\mathrm{HCl}$ at $\mathrm{pH} 8.3,2 \mathrm{mM} \mathrm{MgCl}_{2}, 200$ $\mu \mathrm{M}$ dNTPs|. PCR cycles were as follows: $95^{\circ} \mathrm{C}$ for $5 \mathrm{~min}_{\text {; fol- }}$ lowed by five cycles of $95^{\circ} \mathrm{C}$ for $30 \mathrm{sec}, 70^{\circ} \mathrm{C}$ for $30 \mathrm{sec}, 72^{\circ} \mathrm{C}$ for

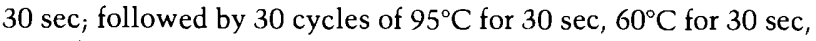
$72^{\circ} \mathrm{C}$ for $30 \mathrm{sec}$. PCR products were electrophoresed on $2 \%$ agarose gels, blotted to nylon membrane, and hybridized with radiolabeled gene-specific probes. Hybridization signal was quantified by direct PhosphorImager (Molecular Dynamics) analysis of Southern blots.

\section{RNase protection}

RNase protection and the Nkx2-5, myosin light-chain $\alpha$, myosin light-chain $\beta$, and GAPDH probes were as described (Lints et al. 1993). The $\alpha C A$ probe was transcribed with T3 polymerase (Promega) from the EcoRI-linearized plasmid LK584 (supplied by Edna Hardeman, Children's Medical Research Institute, Sydney, Australia), a 130-bp genomic BamHI fragment spanning exon 1 cloned into $\mathrm{pBS}$. The $M L C 1 A$ probe was transcribed with T3 polymerase from the EcoRI-linearized plasmid BSLCl A /supplied by Edna Hardeman), a 168-bp genomic EcoRI-HindIII fragment spanning exon 7 cloned into pBS. The $M L C 2 V$ probe was transcribed with T7 polymerase (Promega) from the BamHIlinearized plasmid pcMLC2V (supplied by Kenneth Chien, University of California, San Diegol, a 449-bp partial-length cDNA cloned into pBS. The troponin I probe was transcribed with SP6 polymerase (Promega) from the EcoRI-linearized plasmid PG 105 (supplied by Edna Hardeman), a 250-bp EcoRI-Bg/II fragment of the rat troponin I cDNA cloned into pGEM3. Troponin I hybrids were digested with $2 \mu \mathrm{g} / \mathrm{ml}$ RNase A and $0.1 \mu \mathrm{g} / \mathrm{ml}$ RNase $\mathrm{T} 1$ at $16^{\circ} \mathrm{C}$ for $30 \mathrm{~min}$.

\section{In situ hybridization}

In situ hybridization to sections was performed as described (Senior et al. 1988) with modifications. Probes were synthesized from DNA templates using ${ }^{33} \mathrm{P} \mid \mathrm{UTP}(1000-3000 \mathrm{Ci} / \mathrm{mmole})$ and T3, T7, or SP6 polymerase. Proteinase $\mathrm{K}$ was used at 2 $\mu \mathrm{g} / \mathrm{ml}$ for $30 \mathrm{~min}$ at room temperature. Sections were hybridized overnight at $50^{\circ} \mathrm{C}$ in $50 \%$ deionized formamide, $0.3 \mathrm{M}$ $\mathrm{NaCl}, 10 \mathrm{~mm}$ Tris- $\mathrm{HCl}\left(\mathrm{pH}\right.$ 7.5), $5 \mathrm{~mm}$ EDTA, $10 \mathrm{~mm} \mathrm{Na}_{2} \mathrm{HPO}$, $10 \%$ dextran sulfate, $1 \mathrm{mg} / \mathrm{ml}$ yeast total RNA and $50-100 \mathrm{ng} /$ $\mathrm{ml}$ of RNA probe. Final washing was in $2 \times \mathrm{SSC}$ at $65^{\circ} \mathrm{C}$, before dehydration through an ethanol series for autoradiography. Templates for probe synthesis were as described above or as follows: The $M H C \beta$ probe was synthesized with $\mathrm{T} 7$ polymerase from the HindIII-linearized plasmid MHC 368 , containing a trimer of a 69-bp fragment derived from the 3' UTR of rat MHC $\beta$ cDNA cloned into pBS (supplied by Gary Lyons, University of Wisconsin Medical School, Madison). The cyclin D2 probe was synthesized with $\mathrm{T} 7$ polymerase from the $\mathrm{XbaI}$-linearized plasmid pCN3-CYL2, a 0.7-kb partial cDNA fragment cloned into pBS-SK (supplied by Jerry Adams, The Walter and Eliza Hall Institute of Medical Research, Melbourne, Australia).

Whole-mount in situ hybridization was performed essentially as described (Wilkinson 1992), but with substitution of $0.1 \%$ CHAPS (Sigma) for Tween 20 in washing buffers. Embryos were dissected from their decidua and fixed in $4 \%$ paraformaldehyde overnight at $4^{\circ} \mathrm{C}$. Riboprobes were synthesized from linearized plasmids in the presence of digoxygenin-UTP (Boehringer Mannheim) as per manufacturer's instructions. Hybridization was detected by treating embryos with alkaline phosphatasecoupled anti-digoxygenin antibodies (Boehringer Mannheim), followed by reaction with NBT and BCIP. The $\alpha C A, M L C 2 A$, and $M L C 2 V$ probes were prepared from plasmids described above. The $M E F 2 C$ probe (supplied by Gary Lyons) was synthesized with T3 polymerase from the HindIII-linearized plasmid pMEF2C, containing a $1.6-\mathrm{kb}$ fragment of the MEF2C cDNA cloned into pBS-SKII.

\section{Electron microscopy}

Embryos were fixed in 4\% paraformaldehyde, 2.5\% glutaraldehyde in PBS (pH 7.4) overnight, rinsed three times in PBS, and postfixed in $2 \%$ aqueous osmium tetroxide for $1 \mathrm{hr}$ at room temperature. Embryos were stained with $0.5 \%$ aqueous uranyl acetate, washed in $\mathrm{H}_{2} \mathrm{O}$, dehydrated in a graded acetone series, substituted with Polarbed 812, and polymerized overnight at $65^{\circ} \mathrm{C}$. Sections were cut on a Reichert-Jung Ultracut E, collected on formvar and carbon-coated copper grids, then stained with uranyl acetate and Reynold's Lead Citrate. Grids were imaged on a Philips CM12 microscope.

\section{Acknowledgments}

R.H. and I.L. dedicate this work to the late J.R.E. Wells. We thank Thierry Lints for critical discussions throughout the course of this work. We also thank Edna Hardeman, Eric Olson, Kenneth Chien, and Gary Lyons for sending probes, Terry Huebert for technical assistance, Steven Mihajlovic for histology, Rosemary van Driel for electron microscopy, Kim Patane, Jo Parnese, and their colleagues for animal husbandry, Ashley Dunn and his colleagues for advice on gene targeting, Brandon Wainwright and Sue Monkley for advice on whole-mount in situ hybridization, and David Vaux and Glenn Begley for critique of the manuscript. This work was supported by funds from the National Health and Medical Research Council (Australia), the National Heart Foundation of Australia, and the National Institute of Child Health and Human Development, DHHS (USA) (HD26024-01). R.H. holds an Australian Research Council Research Fellowship; L.P. holds a National Heart Foundation Postgraduate Science Research Scholarship.

The publication costs of this article were defrayed in part by payment of page charges. This article must therefore be hereby marked "advertisement" in accordance with 18 USC section 1734 solely to indicate this fact.

\section{References}

Amacher, S.L., J.N. Buskin, and S.D. Hauschka. 1993. Multiple regulatory elements contribute differentially to muscle creatine kinase enhancer activity in skeletal and cardiac muscle. Mol. Cell. Biol. 13: 2753-2764.

Azpiazu, N. and M. Frasch. 1993. tinman and bagpipe: Two homeo box genes that determine cell fates in the dorsal mesoderm of Drosophila. Genes \& Dev. 7: 1325-1340.

Bengal, E., L. Ransone, R. Scharfmann, V.J. Dwarki, S.J. Tapscott, H. Weintraub, and I.M. Verma. 1992. Functional antagonism between c-Jun and MyoD proteins: A direct physical association. Cell 68: 507-519.

Bodmer, R. 1993. The gene tinman is required for specification of the heart and visceral muscles in Drosophila. Develop ment 118: 719-729.

1995. Heart development in Drosophila and its relationship to vertebrates. TCM (in press). 
Bodmer, R., L.Y. Jan, and Y.N. Jan. 1990. A new homeoboxcontaining gene, $m s h-2$, is transiently expressed early during mesoderm formation in Drosophila. Development 110: 661669.

Bradley, A. 1987. Production and analysis of chimaeric mice. In Teratocarcinomas and embryonic stem cells: A practical approach (ed. E.J. Robertson), pp. 113-151. IRL Press, Washington, DC.

Buckingham, M.E. 1994. Muscle: The regulation of myogenesis. Curr. Opin. Genet. Dev. 4: 745-751.

Burgess, R., P. Cserjesi, and E.N. Olson. 1994. A novel basic helix-loop-helix protein expressed in paraxial mesoderm and immature somites of mouse embryos and in heart and skeletal muscle of the adult mouse. /. Cell. Biochem. (Suppl.) 18D: 487.

Chen, Z., G.A. Freidreich, and P. Soriano. 1994. Transcriptional enhancer factor 1 disruption by a retroviral gene trap leads to heart defects and embryonic lethality in mice. Genes \& Dev. 8: 2293-2301.

Chomzynski, P. and N. Saachi. 1987. Single step method of RNA isolation by acid guanidinium thiocyanate-phenolchloroform extraction. Anal. Biochem. 162: 156-159.

Christensen, T.H., H. Prentice, R. Gahlmann, and L. Kedes. 1993. Regulation of the human cardiac/slow-twitch troponin C gene by multiple, cooperative, cell-type-specific, and myoD-responsive elements. Mol. Cell. Biol. 13: 6752-6765.

Edmondson, D.G., G.E. Lyons, J.F. Martin, and E.N. Olson. 1994. Mef2 gene expression marks the cardiac and skeletal muscle lineages during mouse embryogenesis. Development 120: 1251-1263.

Evans, S.M., L.-J. Tai, V.P. Tan, C.B. Newton, and K.R. Chien. 1994. Heterokaryons of cardiac myocytes and fibroblasts reveal the lack of dominance of the cardiac phenotype. Mol. Cell. Biol. 14: 4269-4279.

Farrance, I.K.G., J.H. Mar, and C.P. Ordahl. 1992. M-CAT binding factor is related to the SV40 enhancer binding factor, TEF-1. J. Biol. Chem. 267: 17234-17240.

Gehring, W.J., Y.Q. Qian, M. Billeter, K. Furukubo-Tokunaga, A.F. Schier, D. Resendez-Perez, M. Affolter, G. Otting, and K. Wuthrich. 1994. Homeodomain-DNA Recognition. Cell 78: 211-223.

Goncharova, E.J., Z. Kam, and B. Geiger. 1992. The involvement of adherens junction components in myofibrillogenesis in cultured cardiac myocytes. Development 114: 173-183.

Grepin, C., L. Dagnino, L. Robitaille, L. Haberstroh, T. Antakly, and M. Nemer. 1994. A hormone-encoding gene identifies a pathway for cardiac but Not skeletal muscle gene transcription. Mol. Cell. Biol. 14: 3115-3129.

Gu, W., J.W. Schneider, G. Condorelli, S. Kaushai, V. Mahdavi, and B. Nadal-Ginard. 1993. Interaction of myogenic factors and the retinoblastoma protein mediates muscle cell commitment and differentiation. Cell 72: 309-324.

Gupta, M.P., M. Gupta, R. Zak, and V.P. Sukhatme. 1991. Egr-1, a serum-inducible zinc finger protein, regulates transcription of the rat cardiac $\alpha$-myosin heavy chain gene. J. Biol. Chem. 266: 12813-12816.

Heikinheimo, M., J.M. Scandrett, and D.B. Wilson. 1994. Localization of transcription factor GATA-4 to regions of the mouse embryo involved in cardiac development. Dev. Biol. 164: 361-373.

Himmelbauer, H., R.P. Harvey, N.G. Copeland, N.A. Jenkins, and L.M. Silver. 1995. High-resolution genetic analysis of a deletion on mouse Chromosome 17 extending over the fused, tufted, and homeobox Nkx2-5 loci. Mammalian Genome 5: 814-816.

Hooper, M.L., K. Hardy, A. Handyside, S. Hunter, and M. Monk.
1987. HPRT-deficient (Lesch-Nyhan) mouse embryos derived from germline colonization by cultured cells. Nature 326: 292-295.

Itasaki, N., H. Nakamura, H. Sumida, and M. Yasuda. 1991. Actin bundles on the right side in the caudal part of the heart tube play a role in dextro-looping in the embryonic chick heart. Anat. Embryol. 183: 29-39.

Jacks, T., T.S. Shih, E.M. Schmitt, R.T. Bronson, A. Bernards, and R.A. Weinberg. 1994. Tumour predisposition in mice heterozygous for a targeted mutation in Nf1. Nature Genet 7: 353-361.

Jacobson, A.G. and A.K. Sater. 1988. Features of embryonic induction. Development 104: 341-359.

Kaushal, S., J.W. Schneider, B. Nadal-Ginard, and V. Mahdavi. 1994. Activation of the myogenic lineage by MEF2A, a factor that induces and cooperates with MyoD. Science 266: 12361240.

Kim, Y. and M. Nirenberg. 1989. Drosophila NK-homeobox genes. Proc. Natl. Acad. Sci. 86: 7716-7720.

Komuro, I. and S. Izumo. 1993. Csx: A murine homeobox-containing gene specifically expressed in the developing heart. Proc. Natl. Acad. Sci. 90: 8145-8149.

Kubalak, S.W., W.C. Miller-Hance, T. O'Brien, E. Dyson, and K.R. Chien. 1994. Chamber specification of atrial myosin light chain-2 expression precedes septation during murine cardiogenesis. I. Biol. Chem. 269: 16961-16970.

Laird, P.W., A. Xijderveld, K. Linders, M. Rudnicki, R. Jaenisch, and A. Berns. 1991. Simplified mammalian DNA isolation procedure. Nucleic Acids Res. 19: 4293.

Lassar, A. and A. Munsterberg. 1994. Wiring diagrams: Regulatory cicuits and the control of skeletal myogenesis. Curr. Opin. Cell Biol. 6: 432-442.

Layton, W.M., M.D. Manasek, and D.M.D. Manasek. 1980. Cardiac looping in early iv/iv mouse embryos. In Etiology and morphogenesis of congenital heart disease led. R. Van Pragh), pp. 109-126. Futura, Mount Kisco, New York.

Lints, T.J., L.M. Parsons, L. Hartley, I. Lyons, and R.P. Harvey. 1993. Nkx-2.5: A novel murine homeobox gene expressed in early heart progenitor cells and their myogenic descendants. Development 119: 419-431.

Litvin, J., M.O. Montgomery, D.J. Goldhamer, C.P. Emerson, and D.M. Bader. 1993. Identification of DNA-binding protein $(\mathrm{s})$ in the developing heart. Dev. Biol. 156: 409-417.

Logan, M. and T. Mohun. 1993. Induction of cardiac muscle differentiation in isolated animal pole explants of Xenopus laevis embryos. Development 118: 865-875.

Lyons, G.E. 1994. In situ analysis of the cardiac muscle gene program during embryogenesis. TCM 4: 70-77.

Lyons, G.E., S. Schiaffino, D. Sassoon, P. Barton, and M. Buckingham. 1990. Developmental regulation of myosin gene ex pression in mouse cardiac cells. /. Cell. Biol. 111: 24272436.

Malhotra, A., S. Huang, and A. Bhan. 1979. Subunit function in cardiac myosin: Effect of removal of Lc2 (18000 molecular weight) on enzymatic properties. Biochemistry 18: 461467.

Manasek, F.J. 1976. Interactions involved in cardiac morphogenesis. In The cell surface in animal embryogenesis and development (ed. G. Poste, and G.C. Nicholson), pp. 545598. North-Holland, Amsterdam, Holland.

Manasek, F.J., B. Burnside, and R.E. Waterman. 1972. Myocardial cell shape change as a mechanism of embryonic heart looping. Dev. Biol. 29: 349-371.

Manasek, F.J., R.R. Kulikowski, and L. Fitzpatrick. 1978. Cytodifferentiation: A causal antecedent of looping? Birth Defects: Original Article Series 14: 161-178. 
Mar, J.H., P.B. Antin, T.A. Cooper, and C.P. Ordahl. 1988. Analysis of the upstream regions governing expression of the chicken cardiac troponin $\mathrm{T}$ gene in embryonic cardiac and skeletal muscle cells. /. Cell Biol. 107: 573-585.

Miwa, T. and L. Kedes. 1987. Duplication CArG box domains have positive and mutually dependent regulatory roles in expression of the human $\alpha$-cardiac actin gene. Mol. Cell. Biol. 7: 2802-2813.

Moens, C.B., B.R. Stanton, L.F. Parada, and J. Rossant. 1993. Defects in heart and lung development in compound heterozygotes for two different targeted mutations at the $N-m y c$ locus. Development 119: 485-499.

Molkentin, J.D., R.S. Brogan, S.M. Jobe, and B.E. Markham. 1993. Expression of the $\alpha$-myosin heavy chain gene in the heart is regulated in part by and E-box-dependent mechanism. J. Biol. Chem. 268: 2602-2609.

Montgomery, M.O., J. Litvin, A. Gonzalez-Sanchez, and D. Bader. 1994. Staging of commitment and differentiation of avian cardiac myocytes. Dev. Biol. 164: 63-71.

Murre, C., P.S. McCow, H. Vassin, M. Caudy, L.Y. Jan, Y.N. Jan, C.V. Cabrera, J.N. Buskin, S.D. Hauschka, and H. Lassar. 1989. Interactions between heterologous helix-loop-helix proteins generate complexes that bind specifically to a common DNA sequence. Cell 58: 537-544.

Navankasattusas, S., H. Zhu, A.V. Garcia, S.M. Evans, and K.R. Chien. 1992. A ubiquitous factor (Hf-la) and a distinct muscle factor (Hf-1b/MEF2) form an E-box-independent pathway for cardiac muscle gene expression. Mol. Cell. Biol. 12: 1469-1479.

Navankasattusas, S., M. Sawadogo, M. van Bilsen, C.V. Dang, and K.R. Chien. 1994. The basic helix-loop-helix protein upstream stimulating factor regulates the cardiac ventricular myosin light-chain 2 gene via independent cis regulatory elements. Mol. Cell. Biol. 14: 7331-7339.

O'Brien, T.X., K.J. Lee, and K.R. Chien. 1993. Positional specification of ventricular myosin light chain- 2 expression in the primitive murine heart tube. Proc. Natl. Acad. Sci. 90: 5157-5161.

Okkema, P.G. and A. Fire. 1994. The Caenorhabditis elegans NK-2 class homeoprotein CEH-22 is involved in combinatorial activation of gene expression in pharyngeal muscle. Development 120: 2175-2186.

Olson, E. 1993. Regulation of muscle transcription by the MyoD family: The heart of the matter. Circ. Res. 72: 1-6.

Olson, E. and W.H. Klein. 1994. bHLH factors in muscle development: Deadlines and commitment, what to leave in and what to leave out. Genes \& Dev. 8: 1-8.

Parmacek, M.S., A.J. Vora, T. Shen, E. Barr, F. Jung, and J.M. Leiden. 1992. Identification and characterization of a cardiac-specific transcriptional regulatory element in the slow / cardiac troponin C gene. Mol. Cell. Biol. 12: 1967-1976.

Robbins, J., J. Gulick, A. Sanchez, P. Howles, and T. Doetschman. 1990. Mouse embryonic stem cells express the cardiac myosin heavy chain genes during development in vitro. $I$. Biol. Chem. 265: 11905-11909.

Rudnicki, M.A., P.N.J. Schnegelsberg, R.H. Stead, T. Braun, H.H. Arnold, and R. Jaenisch. 1993. MyoD or Myf5 is required for the formation of skeletal muscle. Cell 75: 1351-1359.

Rumyantsev, P.P. 1977. Interrelations of the proliferation and differentiation processes during cardiac myogenesis and regeneration. Int. Rev. Cytol. 51: 187-273.

Rupp, R.A.W., L. Snider, and H. Weintraub. 1994. Xenopus embryos regulate the nuclear localization of XMyoD. Genes \& Dev. 8: 1311-1323.

Sartorelli, V., N.A. Hong, N.H. Bishopric, and L. Kedes. 1992. Myocardial activation of the human cardiac alpha-actin pro- moter by helix-loop-helix proteins. Proc. Natl. Acad. Sci. 89: 4047-4051.

Sater, A.K. and A.G. Jacobson. 1990a. The restriction of the heart morphogenetic field in Xenopus laevis. Dev. Biol. 140: 328-336.

$1990 \mathrm{~b}$. The role of the dorsal lip in induction of heart mesoderm in Xenopus laevis. Development 108: 461-470.

Schneider, J.W., W. Gu, L. Zhu, V. Mahdavi, and B. Nadal-Ginard. 1994. Reversal of terminal differentiation mediated by p107 in Rb-/ - muscle cells. Science 264: 1467-1471.

Scott, M.P. 1994. Intimations of a Creature. Cell 79: 1121-1124.

Senior, P.V., D.R. Critchley, F. Beck, R.A. Walker, and J.M. Varley. 1988. The localization of laminin mRNA and protein in the postimplantation embryo and placenta of the mouse: An in situ and immunocytochemical study. Development 104: 431-446.

Thomas, K.R. and M.R. Capecchi. 1986. Site-directed mutagenesis by gene targeting in mouse embryo-derived stem cells. Cell 51: 503-512.

Tonissen, K.F., T.A. Drysdale, T.J. Lints, R.P. Harvey, and P.A. Krieg. 1994. XNkx2.5, a Xenopus gene related to $N k x-2.5$ and tinman: Evidence for a conserved role in cardiac development. Dev. Biol. 162: 325-328.

Vincent, K., A. Gualberto, C. Patel, and K. Walsh. 1993. Different regulatory sequences control creatine kinase- $M$ gene ex pression in directly injected skeletal and cardiac muscle. Mol. Cell. Biol. 13: 1264-1272.

Viragh, S. and C.E. Challice. 1977. Origin and differentiation of cardiac muscle cells in the mouse. J. Ultrastruct. Res. 42: 124.

Weintraub, H., R.L. Tapscott, R.L. Davis, M.J. Thayer, M.A. Adam, A.B. Lassar, and A.D. Miller. 1989. Activation of muscle specific genes in pigment, nerve, fat, liver and fibroblast cell lines by forced expression of MyoD. Proc. Nat1. Acad. Sci. 86: 5434-5438.

Weintraub, H., R. Davis, S. Tapscott, M. Thayer, M. Krause, R Benezra, T.K. Blackwell, D. Turner, R. Rupp, S. Hollenberg, Y. Zhuang, and A. Lassar. 1991. The myoD gene family: Nodal point during specification of the muscle cell lineage. Science 251: 761-766.

Wilkinson, D.G. 1992. Whole mount in situ hybridization of vertebrate embryos. In In situ hybridization: A practical approach (ed. D.G. Wilkinson), pp. 75-84. Oxford University Press, Oxford, UK.

Wobus, A.M., G. Wallukat, and J. Hescheler. 1991. Pluripotent mouse embryonic stem cells are able to differentiate into cardiomyocytes expressing chronotropic responses to adrenergic and cholinergic agents and $\mathrm{Ca} 2+$ channel blockers. Differentiation 48: 173-182.

Wurst, W. and A. Joyner. 1993. Production of targeted embryonic stem cell clones. In Gene targeting a practical approach (ed. A.L. Joyner), pp. 33-61. Oxford University Press, New York.

Zhu, H., V.T.B. Nguyen, A.B. Brown, A. Pourhosseini, A.V. Garcia, M. van Bilsen, and K. Chien. 1993. A novel, tissue-restricted zinc finger protein (HF- $\mathrm{lb}$ ) binds to the cardiac regulatory element (HF-1B/MEF-2) in the rat myosin lightchain 2 gene. Mol. Cell. Biol. 13: 4432-4444. 


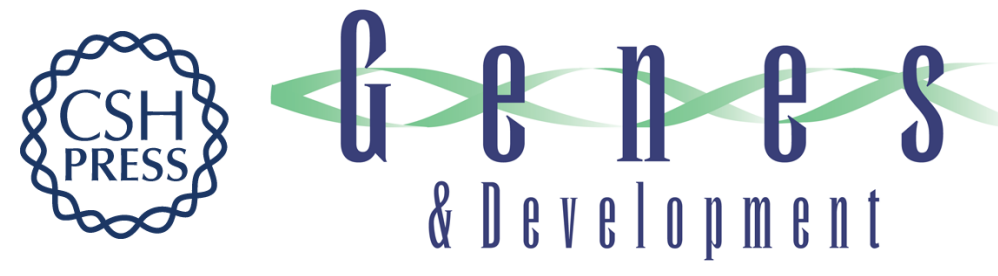

\section{Myogenic and morphogenetic defects in the heart tubes of murine embryos lacking the homeo box gene Nkx2-5.}

I Lyons, L M Parsons, L Hartley, et al.

Genes Dev. 1995, 9:

Access the most recent version at doi:10.1101/gad.9.13.1654

References This article cites 69 articles, 39 of which can be accessed free at:

http://genesdev.cshlp.org/content/9/13/1654.full.html\#ref-list-1

License

Email Alerting

Service

Receive free email alerts when new articles cite this article - sign up in the box at the top right corner of the article or click here.

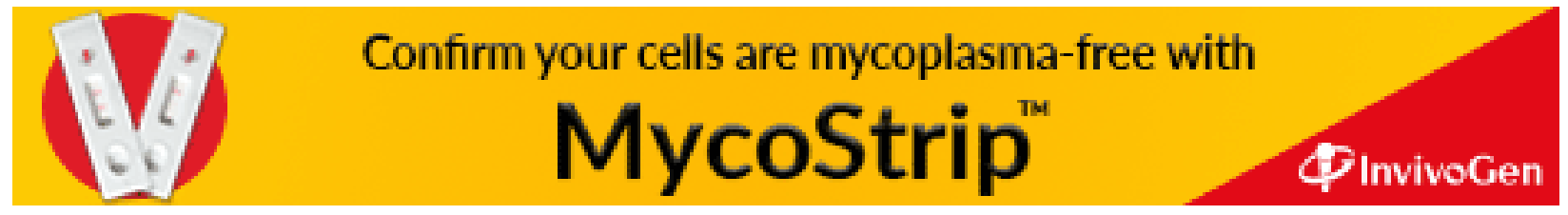

